 \\ z Filologii Polskiej i Słowiańskiej
}

\author{
Helena Krasowska \\ (Instytut Slawistyki Polskiej Akademii Nauk, Warszawa)
}

\section{Problematyka pożyczek ukraińskich w polskiej gwarze górali bukowińskich ${ }^{1}$}

Bukowina jest to kraina leżąca na północno-wschodnim stoku Karpat, przejęta w roku 1774 przez Austrię od Turcji, o obszarze około $10440 \mathrm{~km}^{2}$. Do tego czasu region pozbawiony był samodzielnego znaczenia politycznego. Nie miał też wyraźnie określonych granic. Od przełomu XIV/XV wieku Bukowina była integralną częścią Mołdawii, a od połowy XVI wieku wraz z nią pozostawała pod panowaniem tureckim. Jedynie północno-zachodni skrawek ziemi bukowińskiej od czasów Kazimierza Wielkiego kilkakrotnie dostawał się pod panowanie polskie. Nigdy jednak Bukowina jako całość nie była częścią składową państwa polskiego (Feleszko, 1992, s. 7).

Po pierwszym rozbiorze Polski (1772 rok) Małopolska i Ruś Czerwona weszły w skład Austrii jako prowincja - Galicja (Jurecki, 2000, s. 68), do której

${ }^{1}$ Publikacja naukowa finansowana w ramach programu Ministra Nauki i Szkolnictwa Wyższego pod nazwą „Narodowy Program Rozwoju Humanistyki” w latach 2015-2018, nr projektu 1bH 15035483.

This is an Open Access article distributed under the terms of the Creative Commons Attribution 3.0 PL License (creativecommons.org/licenses/by/3.0/pl/), which permits redistribution, commercial and non-commercial, provided that the article is properly cited. () The Author(s) 2017.

Publisher: Institute of Slavic Studies, Polish Academy of Sciences

[Wydawca: Instytut Slawistyki Polskiej Akademii Nauk] 
w 1787 roku dołączono Bukowinę. W 1849 roku Bukowina uzyskała status księstwa - odrębnego kraju koronnego Austrii (od 1867 roku Austro-Węgier). Po pierwszej wojnie światowej stała się prowincją rumuńską. W 1944 roku, w wyniku aneksji jej północnej części przez ZSSR, została podzielona. Obecnie północna cześć Bukowiny, zamieszkiwana w większości przez Ukraińców (jako obwód czerniowiecki - Чернівецька область), znajduje się w granicach dzisiejszej Ukrainy, jej południowa część, zamieszkiwana w większości przez Rumunów - w granicach Rumunii.

Polacy migrowali na Bukowinę z trzech kierunków: z południowo-wschodniej Galicji, Małopolski oraz rejonu Czadcy, obecnie leżącego w granicach Słowacji. Najbardziej charakterystyczny jest trzeci z wymienionych kierunków - szlak górali. Korzenie tej grupy sięgają daleko w przeszłość południowego Śląska i pogranicza śląsko-małopolskiego. Począwszy od 1803 roku, w wyniku przeludnienia rejonu czadeckiego, rozpoczęła się migracja górali na Bukowinę. Dzisiaj w zwartym skupisku mieszkają oni w Starej Hucie, Terebleczu i Dolnych Piotrowcach (Ukraina) oraz w Nowym Sołońcu, Pojanie Mikuli i Pleszy (Rumunia). Pomijając sprawę innych cech języka górali polskich na Bukowinie, w artykule tym zajmę się problemem pożyczek ukraińskich.

W polskiej gwarze górali bukowińskich, która od przeszło 200 lat rozwijała się poza zwartym obszarem języka polskiego, w obcym środowisku językowym, znaczny procent słownictwa stanowią zapożyczenia pochodzące z sąsiednich języków. Warunki historyczne, kulturalne i językowe, w jakich znaleźli się górale bukowińscy, wpływy kontaktów językowych i wielojęzyczność otoczenia wpłynęły na liczbę i charakter zapożyczeń leksykalnych. Szybkość i kierunek zmian w zasobie leksykalnym górali bukowińskich zależy w dużej mierze od najbliższego otoczenia, tj. środowiska w miejscu zamieszkania. Warunki życia po przesiedleniu, jak również długi okres pobytu w zamkniętej enklawie sprzyjały tym procesom. Na terytorium Bukowiny zamieszkiwali i zamieszkują grupy różnych nacji, mówiące różnymi językami. W tym tyglu językowym górale musieli się więc zaadaptować, między innymi poprzez przejmowanie nowego słownictwa. Również zmiany cywilizacyjne wymuszały używanie nowych słów pochodzących z języka otaczającej większości.

Górale bukowińscy z Nowego Sołońca i Pleszy w większości dojeżdżali do pracy w kopalni soli w Kaczyce, w której pracowało wielu Polaków pochodzących z Galicji, lecz także zatrudnieni byli Ukraińcy i Rumuni. W Starej Hucie górale pracowali wraz z Niemcami w hucie szkła, założonej przez Niemca. Polacy z Pojany Mikuli i Starej Huty często szukali zatrudnienia w lesie, gdzie 
pracowało wielu Rumunów. Zdarzało się też, że wypasali owce w górach; są to jednak sporadyczne wypadki. Pasterstwem zajmowali się tu przeważnie Rumuni, którzy zatrudniali czasami Polaków. Po drugiej wojnie światowej mieszkańcy Dolnych Piotrowiec, Starej Huty i Tereblecza zmuszeni byli pracować w kołchozach, gdzie panował język rosyjski, a z czasem - ukraiński. Poza tym górale, którzy mieszkali we wsiach mieszanych (Tereblecze), musieli ze względów administracyjnych pozostawać w stałym kontakcie z Niemcami, później zaś z Rumunami lub Ukraińcami. Wzorowali się więc na budownictwie, sposobie gospodarowania czy ubierania się tej grupy narodowej, do której należała władza państwowa.

W prowadzonych przeze mnie badaniach leksykalnych posłużyłam się kwestionariuszem Ogólnokarpackiego atlasu dialektologicznego (dalej: OKAD) ${ }^{2}$. Kwestionariusz ten zawiera 785 pytań, które podzielono na dwa rodzaje: a) pytania wychodzące od wyrazu, np. co znaczy: kucza; b) pytania wychodzące od desygnatu, np. jak nazywa się 'płot'?

Wybrałam kwestionariusz OKAD, ponieważ: a) geograficznie Bukowina położona jest w areale karpackim; b) istniała możliwość porównania słownictwa górali bukowińskich z zasięgami zjawisk językowych skartografowanych w pięciu tomach Atlasu; c) kwestionariusz merytorycznie odpowiada problematyce badawczej i rodzajom zajęć mieszkańców badanych wsi.

Kwestionariusz ten zawiera piętnaście działów tematycznych; są one bardzo różnorodne. Na przykład w obszernym dziale „Leksyka codzienna” zostały zawarte pytania na temat domu: o budowę domu, o części domu. Znaleźć tu można zagadnienia dotyczące pasterstwa, zwłaszcza zabudowań pasterskich i ich części; ponadto są pytania o wyposażenie mieszkania, w tym związane $\mathrm{z}$ ogniem i narzędziami, którymi posługiwano się w kuchni. W tym dziale mieszczą się kwestie dotyczące noszonej dawniej odzieży, obuwia, dodatków do odzieży, a także rodzajów toreb. Gwiazdką w kwestionariuszu OKAD oddzielono pytania o nazwy naczyń i ich części. W tej części zamieszczono pytania na temat pokarmów oraz spożywania posiłków; dotyczy to głównie wyrobów mlecznych. Tu też znajduje się skąpy zestaw pytań odnoszących się do nazw pokrewieństwa oraz różnych aspektów kultury duchowej.

Stosunkowo mało pytań - tylko 10 - zawartych jest w dziale „Praca w lesie”. Wydaje się, że gdyby liczba pytań w tej części była większa, mogłoby

2 Por. Общекарпатский диалектологический атлас: Вступительный выпуск (вопросник) (OKAD, 1987, ss. 105-179). 
się pojawić ciekawe słownictwo. Głównym zajęciem moich informatorów - ze względu na położenie Bukowiny - była bowiem praca w lesie.

Kwestionariusz OKAD-u został tak pomyślany, by pytania odnosiły się głównie do słownictwa starszego. Charakter kwestionariusza zadecydował zatem o rodzaju otrzymanej leksyki.

Przegląd materiału zebranego ze wszystkich miejscowości pokazał, że 214 wyrazów i desygnatów z kwestionariusza OKAD nie jest znanych góralom bukowińskim, np. chyża 'dom, określenie ogólne', 'stary zniszczony dom', 'izba', 'kuchnia', 'sień' itd., pojata 'przybudówka do domu, do chlewa', 'szopa przystawiona do domu', 'luźno stojąca buda w sadzie, w polu', mosor, masar 'drewniana beczka do przechowywania ziarna', 'naczynie', 'beczka na bryndzę' i inne.

W zebranym materiale znaczną rolę odgrywa słownictwo ukraińskie, które podzieliłam na dwie grupy: rodzime wyrazy ukraińskie i pożyczki przejęte z innych języków przez ukraiński, które stąd zapewne znalazły się w polskiej gwarze górali bukowińskich.

\section{Pożyczki ukraińskie}

bajstruk 'nieślubne dziecko' (Tu). Por. ukr. байстрюк 'ts.' Hrin I (1907-1909, s. 21); huc. bajster, bajstruk, bajstriuk, bajstrun 'bękart, bachor, znajdek, nieślubne dziecko' SHJ (2001, s. 6), AHR (1996, s. 61); też u Kurz (1985, s. 135) bajstruk 'dziecko nieślubne, bękart' lub w ogóle pogardliwie o dziecku. biłycia 'nieużytek, nieurodzajna ziemia' (SHu). Por. ukr. білиця 'kredowa gleba, ziemia' Hrin I (1907-1909, s. 64); ukr. buk. білица 'nieurodzajna ziemia, zła gleba'.

bratki 'grupa ludzi odwiedzająca z kolędą rodziny w Dzień Bożego Narodzenia'. Por. ukr. братство 'rada duchowna kościoła' Hrin I (1907-1909, s. 95); pol. buk. bractwo 'rada starszych mężczyzn przy kościele' SBF (2003, s. 55). Raczej jest to słowotwórcza innowacja bukowińska.

buśko ‘bocian'. Por. ukr. бyзbкo 'bocian' Hrin I (1907-1909, s. 107); huc. buźko 'bocian' SHJ (2001, s. 21); por. ukr. buk. бузьок, бузько 'ts.'.

cercam 'narzędzie do mierzenia długości i szerokości drzewa' (DPu). Por. ukr. сарсама 'narzędzia rzemieślnicze' Hrin IV (1907-1909, s. 103); huc. sarsama 'narzędzia do roboty leśnej' SHJ (2001, s. 206) oraz jako 'narzędzie ciesielskie do pracy w lesie' występuje w 20 punktach na Huculszczyźnie, głównie w okolicach Krasnoila i Berezowa AHR (1996, s. 220). 
chram 'odpust w parafii'. Por. ukr. xpaM 'odpust', 'budynek cerkwi' Hrin IV (1907-1909, s. 412); huc. chram 'odpust; zabawa dla gości, odbywająca się częściowo pod cerkwią, częściowo w domu' SHJ (2001, s. 27); pol. buk. chram 'ts.' SBF (2003, s. 64). Pożyczka ze staro-cerkiewno-słowiańskiego przez ukr.

chwoja 'choina świerka lub sosny' (Tu). Por. ukr. хвоя 'sosna, Pinus sylvestris L' Hrin IV (1907-1909, s. 395); por. ukr. buk. хвоя, фоя 'gałązka choiny', 'igły choiny'; huc. foja, choja 'szpilki drzew iglastych' AHR (1996, s. 163).

czemerica 'trująca roślina, kwitnie na niebiesko' (DPu, SHu, Tu, NSr). Por. ukr. чемериия 'roślina biała Veratrum album L', 'roślina żółta Veratrum Lobellianum', 'roślina czarna Veratrum nigrum' Hrin IV (1907-1909, s. 451); pol. buk. czemerycia 'środek odurzający' SBF (2003, s. 71); ukr. buk. чемерии а 'trująca roślina', 'środek odurzający'.

czyścić 'kastrować samce zwierząt (barana, byka, knura, konia)' (DPu, Tu, NSr,

Pr). Przeważa na Ukrainie w paśmie Karpat OKAD V (1997, s. 79). Por. ukr. чucmumu 'ts.', też pol. czyścić.

druk 'pawąz' (Tu). Por. ukr. $\partial р y \kappa, \partial р ю \kappa$ 'gruba pałka, gruby kij' Hrin I (1907-1909, ss. 449-450); huc. druk 'patyk' SHJ (2001, s. 48).

drymba 'drumla' (DPu, Tu, NSr). Por. ukr. дримбa 'harmonijka ustna' Hrin I (1907-1909, s. 442); rum. drâmbă 'drumla, instrument ludowy' SRP (1970, s. 193); huc. drymba 'instrument muzyczny, sprężynka do grania palcem na ustach' SHJ (2001, s. 48).

$d u d y$ 'mankiety u koszuli' (DPu, SHu, PMr, NSr, Pr). Por. ukr. dydu 'mankiety na rękawach koszuli' Hrin I (1907-1909, s. 453); huc. $d u d y$ 'mankiety kobiecej koszuli, we wschodnich wsiach też męskiej’ SHJ (2001, s. 49). Z prasłow. *duda 'dęty instrument muzyczny składający się z mieszka skórzanego i piszczałek, gajda, piszczałka, fujarka'.

fufola 'kurniawa, śnieg z wiatrem' (Tu, Pr). Por. ukr. фуфалиия, фуфеля, фуферня 'zawierucha' Hrin IV (1907-1909, s. 381). Por. ukr. buk. фуфала 'ts.'; huc. fufeła 'zawierucha, śnieg z wiatrem' SHJ (2001, s. 59); Crân (1938, ss. 268-269) rozważa różne możliwości etymologii.

horbotka 'spódnica składająca się z dwóch niezszytych połówek' (SHu). Por. ukr. buk. горботка 'rodzaj płachty lub zapaski'; pol. buk. horbotka 'rodzaj długiej spódnicy okręcanej wokół bioder, noszonej na wsi’ SBF (2003, s. 102). hreczka 'kasza gryczana, roślina'. Por. ukr. гречкa 'kasza hreczana, roślina' Hrin I (1907-1909, s. 325); też pol. gryka: regionalne, wschodnie, z ukr. SJPD III (1958-1969, s. 113). 
huby pl. 'wargi' (Tu). Por. ukr. zyбu 'usta, wargi'.

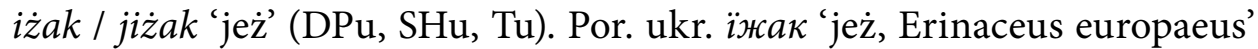
Hrin II (1907-1909, s. 197).

kidryna 'modrzew' (DPu, SHu, Tu). Por. ukr. keдp 'cedr; południowe, wiecznie zielone drzewo' Rud II (1978-1982, s. 651), z łac. cedrus, grec. kédros. Por. huc. kedra, kiedra, kedrowyna, kedryna 'odmiana limby, pinus cembra' SHJ (2001, s. 93).

kłania '30 snopków czegoś, np. lnu' (DPu, SHu, Tu, NSr, Pr). Por. ukr. клань, кланя 'kopy składające się z 30 snopków'; huc. kładnia 'półkopek, 30 snopków' SHJ (2001, s. 96); pol. buk. kłania 'snopy zboża ułożone w stóg' SBF (2003, s. 115), z prasłow. *kladno ESUM II (1982-1989, s. 454).

korczi pl. ‘żylaki na nogach’. Por. ukr. кopui ‘skurcz mięśni, choroba’ ESUM III (1982-1989, s. 46); ukr. buk. корчi ‘żylaki na nogach'.

korczyć 'karczować' (Tu). Por. ukr. корчyватu 'karczować’ Hrin II (1907-1909, s. 289); pol. buk. korczować, kórczować 'karczować, usuwać z korzeniami' SBF (2003, s. 118); tu modyfikacja słowotwórcza.

koriawy 'mający strupy na twarzy'. Por. ukr. buk. корявий 'ts.', z prasłow. *kora 'twarda powłoka przede wszystkim drzewa', 'skorupa np. orzecha, jajka; skórka chleba' SEJPS II (1952-, ss. 471-472); tutaj w innym znaczeniu znanym też w Karpatach ukraińskich.

kozeńka dem. 'koza, mająca od pół roku do roku' (DPu). Por. ukr. кізонька 'mała kózka' Hrin II (1907-1909, s. 243); ukr. buk. кізонька 'ts.'.

kozyczka dem. 'koza, mająca od pół roku do roku' (Tu). Por. ukr. козочка 'koza, zdrobniale' Hrin II (1907-1909, s. 265); ukr. buk. козичка 'ts.'.

koźlik dem. 'koziołek mający od pół roku do roku' (Tu). Por. ukr. козлик 'mały koziołek' Hrin II (1907-1909, s. 266); ukr. buk. козлик 'ts.'.

kukuruza 'kukurydza' (Tu). Por. ukr. кукурудза 'kukurydza' Hrin II (1907-1909,

s. 322); występuje w różnym wariancie fonetycznym na całej Huculszczyźnie AHR (1996, s. 155).

kuliszor 'kijek do mieszania mamałygi'. Por. ukr. кyлеmip 'ts.' Hrin II (1907-1909,

s. 322); huc. kuliszar, kułeszir 'kopystka do mieszania mamałygi' SHJ (2001, s. 109); pol. buk. kuliszyr, kuleszyr, kuliszer 'toczony drążek do mieszania mamałygi podczas gotowania' SBF (2003, s. 123); rum. coleşer 'ts.'.

lachki pl. 'lekkie, płuca' (DPu, SHu, Tu). Por. ukr. легенi 'płuca' Hrin II (1907-1909, s. 350); leheni, lexki w tym znaczeniu na terenie Karpat ukraińskich OKAD IV (1993, s. 18).

liszczyna 'leszczyna drzewo' (Tu). Por. ukr. ліщина 'leszczyna, Coryllus Avellana' Hrin II (1907-1909, s. 373). 
łabuz ‘łodyga kukurydzy’. Por. ukr. лабуз 'liście pokrywające owoce kukurydzy' Hrin II (1907-1909, s. 337); pol. buk. łabuz 'łodyga kukurydzy', 'liście kukurydzy', 'suszona (zielona) kukurydza' SBF (2003, ss. 128-129); powszechne na Bukowinie.

tubek 'wspólne posiedzenie wieczorem przy zmarłym'. Por. ukr. лубок 'rodzaj gry podczas czuwania przy zmarłym'; pol. buk. tubek 'czuwanie nocne przy zmarłym, podczas którego starsi się modlą, a młodsi grają w karty’ SBF (2003, s. 130); huc. łubok 'odwiedziny zmarłego czy zabawa przy zmarłym' SHJ (2001, s. 119), AHR (1996, ss. 83, 84); od лy6 'wewnętrzna część kory, wyrób z niej', jednym z rytuałów gry przy zmarłym jest bicie czymś, co mogło być zrobione z łubu ESUM III (1982-1989, s. 297).

machorka 'tytoń do papierosów' (DPu). Por. ukr. махорка 'rodzaj tytoniu, Nicotiana rustica L'; słc. machorka; bułg. махоркa; jest to pożyczka z języka rosyjskiego ESUM III (1982-1989, s. 420); pol. machorka 'lichy gatunek papierosów’ SJPD IV (1958-1969, s. 356).

mraka 'mgła'. Por. ukr. мряка 'mgła z drobnym deszczem' Hrin II (1907-1909, s. 451); Kurz (1985, s. 206) podaje w znaczeniach 'mgła, pomroka, drobny deszcz', 'zaćmienie umysłowe'; pol. buk. mraka 'mgła' SBF (2003, s. 140); huc. mraka 'mgła' SHJ (2001, s. 130), AHR (1996, s. 249); słc. mrak 'chmura'. nahulane 'nieślubne dziecko' (Tu). Por. ukr. нагуляне od гуляти w znaczeniu '(o dziewczynie) lekko się prowadzić'; potocznie mówi się też нагуляла дитину.

nutr 'niedobrze wykastrowane zwierzę' (Tu). Por. ukr. нутряк 'животное у которого шулята находятся внутри, а не в мошонке' Hrin II (1907-1909, s. 573); ukr. buk. нутер, нютер, нутрецьь 'ts.' SBuk VI (1971-1979, s. 68). paciok 'kastrowany wieprz' ( $\mathrm{DPu}, \mathrm{SHu}, \mathrm{Tu}, \mathrm{NSr}, \mathrm{Pr}$ ). Występuje na terenie Karpat ukraińskich OKAD V (1997, s. 75); por. ukr. пацюк 'kastrowany samiec świni', 'prosię' Hrin III (1907-1909, s. 103); pol. buk. paciuk 'prosię', 'wieprz' SBF (2003, s. 159); też paciuk 'wieprzek' Kurz (1985, s. 213). pantrować 'pilnować. Por. ukr. naнmpyватu 'patrzeć, wypatrywać' i 'pilnować' Hrin III (1907-1909, s. 93); huc. Pantr(uv)aty występuje w 25 punktach na terenie Huculszczyzny, obok też sokotyty, pazyty w tym znaczeniu AHR (1996, s. 255); pol. buk. pantrować 'pilnować, doglądać; wyczekiwać na kogo' SBF (2003, s. 161).

paporoć 'paproć' (SHu, Tu). Por. ukr. nanopoms 'paproć' Hrin III (1907-1909, s. 95). peczerica 'pieczarka'. Por. ukr. печериия 'grzyb, Agaricus campestris L, pieczarka' Hrin III (1907-1909, s. 149); por. huc. peczeryci(a) 'pieczarka’ SHJ (2001, s. 158). 
pieczunka 'wątroba' (DPu, SHu, Tu, NSr, Pr). Por. ukr. neчiнкa 'wątroba' Hrin III (1907-1909, s. 149); choć i por. słc. pečienka 'wątróbka, potrawa', ale pol. buk. pieczonka, pieczunka 'wątroba' SBF (2003, s. 165), adaptacja do polskiej fonetyki. pieriełaz / prielaz 'specjalne miejsce na podwórku z żerdzi, przez które się przechodzi' (Tu). Por. ukr. перелаз 'miejsce, gdzie przechodzą przez opłotek' Hrin III (1907-1909, s. 123); por. huc. perełaz 'przełaz, przejście przez płot' SHJ (2001, s. 160).

pinchur 'pęcherz wodny, odcisk'. Por. ukr. nixyp 'pęcherz na palcach' Hrin III (1907-1909, s. 189); huc. pichur 'pęcherz' SHJ (2001, s. 163); wskazuje na nosowość - jak pęcherz, forma prawdopodobnie ukr. - ur może jak michur, modyfikacja przez wstawione $n$.

pojas 'sznurek podtrzymujący spodnie męskie' (DPu). Por. ukr. nояc 'pas' Hrin III (1907-1909, s. 398).

pokrieśnica f 'chrześnica' (Tu). Por. ukr. похресниця 'ts.' Hrin III (1907-1909, s. 389); huc. pochresnycia 'chrześniaczka' SHJ (2001, s. 169); częste zwłaszcza w okolicy Nadwórnej AHR (1996, s. 48); pol. buk. póksześnica 'chrześniaczka' $\operatorname{SBF}(2003$, s. 176).

pokrieśnik m 'chrześniak' (Tu). Por. ukr. nохресник 'ts.' Hrin III (1907-1909, s. 389);

huc. pochresnyk 'chrześniak' SHJ (2001, s. 169); częste zwłaszcza w okolicy Nadwórnej AHR (1996, s. 47); pol. buk. póksześnik 'chrześniak' SBF (2003, s. 176). pokrywało 'narzuta na łóżko' ( $\mathrm{DPu}, \mathrm{SHu}, \mathrm{Tu})$. Por. ukr. покривало 'przykrycie; kapa, narzuta'.

polica ‘odkładnica, część pługa'. Por. ukr. полиия ‘odkładnica pługa’ Hrin III (1907-1909, s. 283).

polog 1. 'kilka pokosów zbierają do połogu' (DPu), 2. 'roztrzęsione siano' (SHu, PMr, NSr, Pr). Por. ukr. nолiz 'pokos' Hrin III (1907-1909, s. 284); w rum. polog 'pokos; czynność rozrzucania siana; trawa dojrzała do skoszenia' SRP (1970, s. 460), z języków słowiańskich Mih (1960, ss. 31, 226).

pomana 'jałmużna, datek ofiarny'. Por. ukr. помана 'rodzaj babki (kołacza) przeznaczone na jałmużnę w kształcie krzyża’ Hrin III (1907-1909, s. 293); por. rum. pomană 'jałmużna; stypa' SRP (1970, s. 461); pol. buk. pomana, pómana 'rytualny datek lub poczęstunek za dusze zmarłych, jałmużna, datek ofiarny i inne' SBF (2003, s. 170); pomana 'modlitwa za zmarłego'; bułg. pomana, wg. Skoka odczasownikowe od poménuti 'wspominać, wyraz rozpowszechniony na terenach prawosławnych; sporadycznie występuje na Huculszczyźnie w znaczeniu 'sobota zaduszna (sobota poświęcona pamięci zmarłych’ AHR (1996, s. 62). 
riabina 'jarzębina' (Tu). Por. ukr. рябина 'jarzębina, Sorbus aucuparia' Hrin IV (1907-1909, s. 91). Por. ukr. buk. рябіна 'ts.'.

ripak 'rzepak' (SHu, Tu, NSr, Pr, DPu). Por. ukr. pinaא 'rzepak, Brassica napus'

i pina 'rzepa, Brassica rapa' Hrin IV (1907-1909, s. 24).

rypa 'oberwany brzeg, obryw góry' (DPu, SHu, PMr, NSr, Pr). Por. ukr. puna 'urwisko; wysoki oberwany brzeg, obryw' Hrin IV (1907-1909, s. 17); por. huc. rypa 'stromy, wysoki brzeg', repa 'urwisko' SHJ (2001, s. 204); rum. râpă 'urwisko' SRP (1970, s. 522).

ryskol 'rydel, szpadel'. Por. ukr. рискаль 'szpadel' Hrin IV (1907-1909, s. 18); też ryskal ‘łopata żelazem okuta, szpadel, rydel' Kurz (1985, s. 490); huc. ryskal 'rydel, łopata, ryskal' SHJ (2001, s. 204), powszechne na Huculszczyźnie AHR (1996, s. 191); pol. buk. ryskal 'szpadel' SBF (2003, s. 194).

swiniarnik 'pomieszczenie dla świń, osobno wybudowane' (DPu). Por. ukr. свинарник 'ts.' Hrin IV (1907-1909, s. 106); ros. свинарник 'chlewnia, chlew' WSRP II (1996, s. 420).

szipot 'szum wody' (DPu, Tu). Por. ukr. uunom 'źródło wody, lejące się z góry na dół’ Hrin IV (1907-1909, s. 495); huc. szypit 'kamienie, progi w rzece; mały wodospad' SHJ (2001, s. 233).

szulek 'kukurydza, kolba kukurydzy z ziarnem'. Por. ukr. шулька 'ts.' Hrin IV (1907-1909, s. 518); pol. buk. szulka 'kolba kukurydzy z ziarnem' SBF (2003, s. 215); huc. szulka 'owoc kukurydzy', szulok 'strąk kukurydzy z mundurkiem' SHJ (2001, s. 232) (etc!).

(szyna na) koliesie 'obręcz, rafa' (Tu). Por. ukr. шина на колесах 'obręcz na kołach' Hrin IV (1907-1909, s. 495). Na znacznym obszarze w Karpatach występuje nazwa niem. Schiene, poświadczona w OKAD V (1997, s. 16) z dial. ukr., rum. i południowosłowiańskich JSiat1 (2000, s. 232).

szypszyna 'dzika róża' (Tu). Por. ukr. шипшинa 'dzika róża' Hrin IV (1907-1909 , s. 495).

tabaczka 'tytoń do żucia' (DPu, NSr, Pr). Por. ukr. maбачкa 'tabaka', 'roślina Ranunculus sceleratus' Hrin IV (1907-1909, s. 241).

tatusio 'ojciec, tata' (Tu). Por. ukr. mamycbo 'ts.' Hrin IV (1907-1909, s. 250); ukr. buk. mamycbo 'ts.'; Kurz (1985, s. 248) podaje tatusio z Garwolina, Ostrowa Mazowieckiego, Siedlec i polskich wsi w Rumunii.

terebić 'obierać kukurydzę z ziaren'. Por. ukr. mepeбumu 'czyścić, oczyszczać ze strączków' Hrin IV (1907-1909, s. 255); pol. buk. terebić 'obierać kolby kukurydzy z ziarna, łuskać' SBF (2003, s. 222); huc. terebyty 'wytrząsać, oczyszczać; wyrzucać z pola; łuszczyć' SHJ (2001, s. 236). 
tieliatnik 'pastuch cieląt' (SHu, Tu). Por. ukr. телятник 'pastuch cieląt' Hrin IV (1907-1909, s. 253); por. ros. телятник 'cielętnik, jałownik; oborowy od cieląt' WSRP II (1996, s. 576).

trachać się 'określenie stosunku płciowego u królików' (SHu, Tu). Por. ukr. mpaxamu 'pukać np. do drzwi' Hrin IV (1907-1909, s. 279); por. też. wulg. ukr. buk. mрахати, трахнути 'stosunek płciowy u ludzi'; ros. mpaxamь 'trzaskać, hukać, grzmocić, gruchać; trzaskać, walić' WSRP II (1996, s. 599). trina 'pokruszone drobne siano' (DPu, SHu, Tu, NSr, Pr). Por. ukr. трина 'pokruszone siano lub słoma, stęchłe' Hrin IV (1907-1909, s. 283).

tucza 'tęcza, grad' (DPu, SHu, Tu, PMr, NSr). Por. ukr. myua 'burza, nawałnica' Hrin IV (1907-1909, s. 298); huc. tucza 'burza z gradem' SHJ (2001, s. 242). urwa 'przepaść (DPu, SHu, PMr). Por. ukr. урвисько 'obryw' Hrin IV (1907-1909, s. 350); por. ukr. buk. урва 'zerwany brzeg'.

ważki pl. 'lejce, cugle' (DPu, NSr, Pr). Por. ukr. віжки, вожки 'pasy rzemienne połączone z wędzidłem’ ESUM I (1982-1989, s. 396); pol. wodze 'lejce' od czasownika prasłow. * voditi 'wodzić' Vasmer I (1964-1973, s. 332), zmiana i/o w $a$.

wereta 1 . 'tkane płótno, prześcieradło', 2. 'tkane chodniczki na podłogę z wełny' $(\mathrm{SHu}, \mathrm{Tu})$. Por. ukr. вepema 'zgrzebne płótno; rodzaj różnokolorowych dywaników, którymi zaściełano ławki, czasami nawet stół’ Hrin I (1907-1909, s. 135); por. huc. wereta 'płachta płócienna' występuje zwłaszcza często na południowym wschodzie Kołomyi AHR (1996, s. 180); pol. dawne wereta 'prześcieradło, płachta z grubego, zgrzebnego płótna' SJPD IX (1958-1969, s. 930).

wicher 'wir w rzece' (DPu, SHu). Por. ukr. вихор 'wir kurzu na drodze' Hrin I (1907-1909, s. 198); pol. wicher 'silny, gwałtowny wiatr'; też ukr. buk. вихор 'wir kurzu, piasku na drodze', słowo zostało przeniesione na znaczenie 'wir w rzece', nie wyklucza się, że mogło to być jedno ze znaczeń pierwotnych. worynie pl. 'żerdzie używane do ogrodzenia podwórza' (PMr, NSr, Pr). Por. ukr. ворина 'żerdź używana do ogrodzeń' Hrin I (1907-1909, s. 254); por. huc. woryna, worynie 'żerdź; patyki z rozkutych świerków, służące jako materiał do płotków huculskich; płot z ułożonych łat’ SHJ (2001, s. 262).

wremia 1. 'czas' (DPu, Tu, PMr, Pr), 2. 'pogoda' (Tu). Por. ukr. верем'я 'dobra pogoda' Hrin I (1907-1909, s. 135). W rum. vréme 'czas, pogoda' SRP (1970, s. 684) ze wschodniosłowiańskiego Mih (1960, s. 108); por. ros. время 'czas; czasy (epoki); pora, godziny’ WSRP I (1996, s. 154).

wутпо 'wymię: krowy, owcy' (SHu). Por. ukr. buk. вимно, вімнє; ukr. lit. вим'я. 
zarwa 'wąwóz, oberwana ziemia'. Por. ukr. зарва 'obryw ziemi' Hrin II (1907-1909, s. 88); huc. zarwa 'urwisko skalne na polu' SHJ (2001, s. 275).

zarwanica 'wąwóz' (SHu), jw. z suf. -an-ica, ukr. зарваниця.

$z r u b$ 'pole na wykarczowanym lesie' (Tu). Por. ukr. зруб 'miejsce, gdzie zrąbany był las' Hrin II (1907-1909, s. 185); ukr. buk. зруб 'ts.'.

żyr 'owoc buka, bukiew' (Tu). Por. ukr. жup ‘buczyna, owoc buka' Hrin I (1907-1909, s. 485).

\section{Pożyczki przejęte z innych języków przez ukraiński}

barda 'rodzaj siekiery do obciosywania drzewa'. Por. rum. bárdă 'topór ciesielski' SRP (1970, s. 53); ukr. бардa 'siekiera do ciosania drzewa'; pol. buk. barda 'szeroka siekiera do ciosania drzewa' SBF (2003, s. 51); powszechne na Bukowinie; w rum. i mołd. pożyczka z węg. bárd 'siekiera' ESUM I (1982-1989, s. 141). batiar 'stary kawaler, hultaj, pijak' (DPu, SHu, Tu, PMr, NSr). Por. rum. buk. bacher 'człowiek unikający pracy i wchodzący w kolizję z prawem'; ukr. buk. бamap 'ts.'; pol. buk. batiar 'ulicznik, chuligan, łobuz' SBF (2003, s. 51); Kurz (1985, s. 139) podaje batiar, ale i baciar, baciarz'andrus, łobuz, ulicznik' z węg. betyár 'włóczęga, człowiek poza prawem'.

bolfa 'miejsce opuchnięte od uderzenia'. Por. z rum. bólfă 'gula, guz' SRP (1970, s. 67); w ukr. buk. больøбa 'ts' Crân (1938, s. 217).

borkut 'źródło wody mineralnej' (DPu, PMr, Pr). Por. ukr. буркуm 'бьющій ключь, источник кислой минеральной воды’ Hrin I (1907-1909, s. 112); huc. burkut 'źródło kwaśnej (szczawiowej) wody' SHJ (2001, s. 20). Prawdopodobnie pożyczka z węg. borkut 'źródło wody mineralnej'; też rum. burkút 'woda mineralna', w rum. utworzone z tur. bor 'wino' oraz kut 'źródło, studnia' nieznanego pochodzenia ESUM I (1982-1989, s. 231).

bukata 'kawałek czegoś, np. chleba, drogi'. Por. rum. bucată 'kawałek czegoś'; ukr. буката 'kawałek' Hrin I (1907-1909, s. 108); pol. buk. bukata 'wielki kawałek całości; kawałek płótna' SBF (2003, s. 59); huc. bukata 'kąsek, kawałek chleba, czegoś' SHJ (2001, s. 19), AHR (1996, s. 206); z łac. buccata Crân (1938, s. 226).

burdej 1. 'drewniany domek w polu, schronienie od niepogody' (SHu, $\mathrm{PMr}$, NSr, Pr), 2. 'drewniany domek zamieszkały przez osoby starsze, biedne' $(\mathrm{DPu}), 3$. 'pomieszczenie w polu służące do dojenia krów na pastwisku' (SHu, PMr, NSr, Pr). Znane na Ukrainie, Mołdawii i w Rumunii w znacze- 
niach 'biedny, stary domek', 'ziemianka', 'domek, przekrycie od niepogody w polu' i in. OKAD I (1989, s. 3); por. ukr. бypдеŭ 'ziemianka', 'izba kurna' Hrin I (1907-1909, s. 111); prawdopodobnie z rum. burdéi Crân (1938, s. 229); sporadycznie występuje na Huculszczyźnie AHR (1996, s. 171).

carina 1. 'ogólna nazwa pola' (SHu, Tu, NSr, Pr), 2. 'pole zasiane trawą' (DPu). Por. rum. ţárină 'pole uprawne, rola; obszar gminy' SRP (1970, s. 646) z wchsłow. изарина Crân (1938, ss. 233-234); por. ukr. uзарина Hrin IV (1907-1909, s. 423); huc. caryna 'ogród pole; nazwa pola ornego; grządki; pole dalsze od chaty' SHJ (2001, s. 23), por. też AHR (1996, ss. 213, 237); ukr. buk. uзарина; znane też w gwarach Polski m.in. w gwarach łemkowskich z ukr. jako 'ogólna nazwa pola; pole zasiane trawą; łan pola'; 'pole urodzajne, pole, pastwisko, ogrodzone, wrota na pole, wrota wsi' SGPK I (1900-1911, s. 160).

celina 'ziemia, przez jakiś czas nieobrobiona' (SHu). Por. ukr. изілина 'nowe pole, które się pierwszy raz orze' Hrin IV (1907-1909, s. 432); ukr. buk. цілина 'pole na którym uprawiano siano; pole zasiane pod siano'; pol. calina 'ts.'. czuczać 'siadać, w zwrocie do małego dziecka'. Por. rum. ciuciuli 'kulić się' SRP (1970, s. 109); ukr. buk. чyчamu 'w zwrocie do małego dziecka'.

dziżma 1. 'opłata za dzierżawę pola' (Pr), 2. 'podatek oddawany państwu' (Tu). Por. rum. dijmă, déjmă 'czynsz dzierżawny w naturze' SRP (1970, s. 181); ukr. дежмa 'część zbiorów, którą oddawano właścicielowi ziemi', z węg. dézsma 'dziesięcina' ESUM II (1982-1989, s. 24).

dżerha 'narzuta na łóżko z wełny' (SHu). Por. ukr. джергa 'rodzaj zapaski; rodzaj zagłówka z siana lub z koca’ Hrin I (1907-1909, s. 375); huc. dżerga 'podkład z koca pod głowę; płachta z grubego płótna, stara płachta; kocyk pod siodło' SHJ (2001, s. 52); pol. buk. dżerha 'włochaty dywan używany jako przykrycie lub dekoracja na ścianie’ SBF (2003, s. 80); w rum. cérgă 'derka' SRP (1970, s. 99) z tur. čerga Rob (1996, s. 118).

falcze 'miara pola, hektar' ( $\mathrm{DPu}, \mathrm{SHu}, \mathrm{Tu}, \mathrm{NSr}, \mathrm{Pr}$ ). Por. rum. fálce, pol. buk. falcza 'mołdawsko-bukowińska jednostka powierzchni gruntu...' SBF (2003, s. 82); ukr. buk. фальчa 'jednostka powierzchni gruntu'; huc. falcza 'miara ziemi ok. 2 morgi' SHJ (2001, s. 56); Crân (1938, ss. 256-257) rozważa różne etymologie tego słowa; Rob (1996, s. 120) wywodzi z łac. falx, -cis.

fota 'spódnica składająca się z dwóch niezszytych połówek' (DPu, Tu). Por. rum. fótă 'zapaska, fartuch' SRP (1970, s. 230); ukr. øoma 'ts' z tur. fota, Crân (1938, ss. 265-266). 
griża / hryża 'przepuklina'. Por. ukr. buk. грижа 'przepuklina'; w rum. grijă 'troska' z bułg. грижа Rob (1996, s. 143); por. ukr. грижник 'roślina, Herniaria glabra L. i inne' od грижа, гризтu; roślinę tę stosują w medycynie ludowej do leczenia różnych chorób; $\mathrm{z}$ łac. herniaria od hernia 'przepuklina', w niektórych regionach nalewkę $\mathrm{z}$ tej rośliny piją przy bólach po ciężkiej pracy fizycznej lub noszeniu czegoś ciężkiego ESUM I (1982-1989, s. 594).

gusza 'tarczyca, nabrzmienie na szyi z powodu choroby'. Por. z rum. gușă 'podgardle, wole u zwierząt'; w ukr. huc. i innych dialektach karpackich zyma; pol. buk. gusza 'podgardle, wole u kury', 'opuchlizna na szyi człowieka' $\operatorname{SBF}$ (2003, s. 93); Rob (1996, s. 137).

kalfa 'osoba odpowiedzialna za stosowny zapis i zebranie pieniędzy'. Por. rum. cálfă 'czeladnik' SRP (1970, s. 81); ukr. buk. кaлфa 'organizator, przywódca (skarbnik)'; huc. kałfa 'przywódca' SHJ (2001, s. 90); kalfa 'pomocnik kupca, służący', jest to bałkański turcyzm pochodzenia arabskiego, Skok (1971-1974).

kazan 'spiżowy duży garnek, półokrągły'. Por. rum. cazán 'kocioł’ SRP (1970, s. 90); ukr. казан 'ts.' Hrin II (1907-1909, s. 207) z tur. kazan ESUM II (1982-1989, s. 340).

kiptar' 'kamizelka wyszywana kolorowymi nitkami'. Por. z rum. cheptar, pieptár 'serdak' SRP (1970, s. 444); w ukr. кеnтарuк 'rodzaj krótkiego kożuszka bez rękawów’ Hrin II (1907-1909, s. 235); powszechne na terenie huculskim AHR (1996, s. 105); rum. pieptar z łac. pectus Crân (1938, ss. 310-311).

klaka / kłaka 'bezpłatna pomoc sąsiedzka'. Por. ukr. клака 'wspólna praca u sąsiada lub u kogoś z rodziny, tołoka', pożyczka z mołd. клакэ 'pańszczyzna; wspólna praca', też rum. clacă 'ts’. ESUM II (1982-1989, s. 453); ukr. buk. клака 'bezpłatna pomoc sąsiedzka kończąca się zabawą i poczęstunkiem'; pol. buk. kłaka, tłoka 'samopomoc sąsiedzka przy pracach polowych lub domowych' SBF (2003, ss. 115, 223).

koczan 1. 'korek u beczki' (SHu), 2. 'kukurydza oczyszczona od ziaren'. Por. ukr. качан 'kukurydza oczyszczona od ziaren, głąb kapusty' Hrin II (1907-1909, s. 227); ukr. buk. кочин, кочєн, кочан, кочян SBuk IV (1971-1979, s. 89); por. pol. buk. kaczan 'kolba kukurydzy bez ziarna' SBF (2003, s. 108). Tu przeniesione znaczenie, choć przedmiot tak nazywany służy jako korek do butelki. Z tur. kočan 'kaczan' SEJPS II (1952-, s. 14).

kulesza 'mamałyga, potrawa z mąki kukurydzianej'. Por. ukr. кулеша 'jedzenie, ugotowana mąka kukurydziana’ Hrin II (1907-1909, s. 322); huc. kułesza 
'kulesza; gotują ją dosyć gęsto i do jedzenia wrzucają na krążek drewniany, skąd biorą rękami' SHJ (2001, s. 109); por. rum. culeaşa, culeša, węg. köles; rum. buk. culéșă 'jedzenie’ SBF (2003, s. 123).

lica pl. 'uzda' (SHu, Tu). Por. pol. lejce 'ts.', w ukr. лiŭui 'ts.' za pośrednictwem polskiego z niem. Léitseil ESUM III (1982-1989, s. 259); por. ukr. buk. лiu̧a 'ts.'. mamaliga 'mamałyga'. Por. z rum. mămăligă, w ukr. мамалигa 'potrawa z mąki kukurydzianej' SBF (2003, s. 133); Crân (1938, ss. 342-343).

manżet $\mathrm{m}$ / manżeta f'mankiet u koszuli' (Tu, Du). Por. ukr. манжета; pol. buk. manszet 'mankiet'; rum. manșetă SBF (2003, s. 134); por. też czes. i słc. manžeta. Powszechne w gwarach ukraińskich na terenie Bukowiny z franc. manchette. megla 'kupa czegoś, np. drzewa' (DPu, SHu, PMr, NSr). Por. ukr. мигла 'kupa uskładanego drzewa' Hrin II (1907-1909, s. 422); mygła znane na Huculszczyźnie AHR (1996, s. 165); магла, магля 'kupa kłód przygotowanych do spławu' z węg. máglya 'kupa, stos' ESUM III (1982-1989, s. 353); por. rum. mâglă 'ts.' Rob (1996, ss. 190-191).

mohorycz 'poczęstunek po pracy lub po udanej transakcji (wódka i przekąska)'. Por. ukr. могорич 'poczęstunek po pracy (wódka i przekąska)' Hrin II (1907-1909, s. 438); huc. mohorycz' 'litkup, poczęstunek' SHJ (2001, s. 128); pol. buk. mohorycz 'opicie przez kontrahentów transakcji lub innej udanej sprawy' SBF (2003, s. 139); za pośrednictwem tur. z arabskiego magaridž 'wydatki' ESUM III (1982-1989, s. 494).

nanaszka f 'matka chrzestna' (Tu). Por. rum. naşă 'chrzestna matka' SRP (1970, s. 382); нанашка 'ts.' Hrin II (1907-1909, s. 505); por. ukr. buk. нанашка 'ts.', huc. nanaszka 'ts.' SHJ (2001, s. 136), AHR (1996, s. 46).

nanaszko m 'ojciec chrzestny' (Tu). Por. rum. naș, 'chrzestny ojciec, starosta weselny' SRP (1970, s. 382); ukr. нанашко 'ts.' Hrin II (1907-1909, s. 505); SBF (2003, s. 146) (nănaș), por. ukr. buk. нанашко 'ts.'; huc. nanaszko 'ts.' SHJ (2001, s. 136), AHR (1996, s. 46). W znaczeniu 'rodzice chrzestni' występują te wyrazy w gwarach huculskich, karpackich oraz łemkowskich (Столбунова, 1979, s. 18).

oczkur 'sznurek podtrzymujący spodnie męskie'. Por. ukr. oчkyp 'ts.' Hrin III (1907-1909, s. 82); por. huc. oczkur' 'sznurek przewleczony przez górny brzeg kalesonów, zawiązywany w pasie; sznurek do ściągania kalesonów; sznur' SHJ (2001, s. 146); w ukr. pożyczka turecko-tatarska učkur 'ts.' placinty 'chleb obrzędowy pieczony na Boże Narodzenie'. Por. rum. plăcíntă 'placek nadziewany' SRP (1970, s. 452); ukr. плачинда 'rodzaj placka' Hrin III (1907-1909, s. 193); Rob (1996, s. 204) wywodzi z łac. placenta. 
spuza 1. 'resztki węgla spalonego w piecu'(DPu, PMr), 2. 'kijek do rozgarniania ognia w ognisku' (NSr, Pr), 3. 'zastarzała sadza (która się ciągnie)' (SHu). Por. z rum. spúză '(gorący) popiół' SRP (1970, s. 576); w ukr. cnydзa 'popiół' Hrin IV (1907-1909, s. 191); z łac. spodia Crân (1938, ss. 382-383).

turma 'stado owiec lub bydła'. Por. z rum. túrmă 'stado, trzoda' SRP (1970, s. 644) w ukr. турма 'stado owiec'; w rum. z łac. turma, występuje też w bułg. Rob (1996, s. 232), Crân (1938, s. 403); występuje zwłaszcza w okolicach Horodenki, Śniatynia oraz Kołomyi AHR (1996, s. 228).

W pierwszej grupie, czyli pożyczki ukraińskie, zwracają uwagę wyrazy występujące powszechnie we wszystkich sześciu zbadanych wsiach. Są to: bratki, buśko, chram, hreczka, korczi, koriawy, kuliszor, łabuz, tubek, mraka, pantrować, peczerica, pinchur, polica, pomana, ryskol, szulek, terebić, wereta, zarwa. Należą one do różnych zakresów znaczeniowych związanych z życiem codziennym górali. Najwięcej pożyczek ukraińskich dotyczy uprawiania kukurydzy i związanych z nią nazw części kukurydzy, jak też świąt rodzinnych i kościelnych oraz świąt dorocznych, np. chram, pomana, tubek.

Niektóre ukraińskie wyrazy używane są w pięciu lub czterech badanych wsiach. Wyrazy te można podzielić na: a) znane też w języku rumuńskim, ze słowiańskiego: rypa, wremia; b) wyrazy prasłowiańskie: czyścić, dudy, kłania, paciok, pieczunka, ripak, trina, tucza, wazki.

Rzadziej występują następujące wyrazy: a) w trzech lub dwóch zbadanych wsiach: iżak / jiżak, kidryna, lachki, paporoć, pokrywało, szipot, trachać się, wicher; b) w jednej z sześciu badanych wsi: bajstruk, biłycia, celina, cercam, chwoja, druk, horbotka, huby, korczyć, kozeńka, kozyczka, koźlik, kukuruza, liszczyna, machorka, nahulane, nutr, pieriełaz / prielaz, pojas, pokrieśnica, pokrieśnik, riabina, swiniarnik, szypszyna, tatusio, tieliatnik, wymno, zarwanica, zrub, żyr. Znany językoznawcom jest proces polegający na tym, że język państwowy, w tym wypadku ukraiński, wpływa na gwarę mieszkańców wsi położonych na Bukowinie północnej. Najbardziej podatna na zapożyczenia ukraińskie warstwa leksykalna widoczna jest tu u górali z Tereblecza, gdyż mieszkają tam oni w dużym rozproszeniu.

Niebagatelny problem przedstawia druga grupa pożyczek, tzn. pożyczki dalsze w języku ukraińskim. Na pierwszy plan wysuwają się pożyczki węgierskie w języku rumuńskim i ukraińskim, np. barda, batiar, borkut, dziżma, kulesza, megla. Jak widać, wyrazy te należą do różnej tematyki życia codziennego górali. Kolejną podgrupę tworzą pożyczki z łaciny, które musiały przejść przez język rumuński do ukraińskiego, np. bukata, falcze, griża / hryża, kiptar', placinty, 
spuza, turma. Należy zwrócić uwagę na to, że w tej grupie znajdują się pożyczki przejęte z tureckiego lub poprzez turecki z języka ukraińskiego, np. dżerha, fota, kalfa, kazan, koczan, mohorycz, oczkur.

Z języka rumuńskiego do ukraińskiego przeszły: bolfa, burdej, czuczać, gusza, mamaliga, nanaszka, nanaszko; z niemieckiego za pośrednictwem polskiego - lica; z francuskiego znalazł się manżet / manżeta.

Z powyższego przeglądu widać, że pożyczki ukraińskie stanowią poważny problem interpretacyjny i klasyfikacyjny. Zwłaszcza te z języka węgierskiego, łacińskiego czy tureckiego, które istnieją też w języku rumuńskim. Na pytanie, czy górale przejęli te pożyczki z ukraińskiego, czy z rumuńskiego, nie można dać jednoznacznej odpowiedzi; tym bardziej, że Bukowina w okresie od 1918 do 1944 roku należała do Rumunii i język rumuński był językiem szkół, urzędów itd. Nie wiadomo także, czy wyrazy pochodzenia rumuńskiego przeszły przez język ukraiński, czy też zapożyczone zostały bezpośrednio. To samo dotyczy węgierskiego i niemieckiego. Przedstawiony materiał może być więc traktowany tylko jako jedna z części ogólnego zasobu słownikowego gwary górali bukowińskich. Nie stanowi on także pełnego zestawu zapożyczeń ukraińskich w polskiej gwarze górali na Bukowinie Karpackiej. Może stać się jednak impulsem do dalszych wyczerpujących badań.

Skróty nazw miejscowości

$\mathrm{DPu}$ - Dolne Piotrowce (miejscowość na Ukrainie)

NSr - Nowy Sołoniec (miejscowość w Rumunii)

$\mathrm{PMr}$ - Pojana Mikuli (miejscowość w Rumunii)

Pr - Plesza (miejscowość w Rumunii)

$\mathrm{SHu} \quad$ - Stara Huta (miejscowość na Ukrainie)

Tu - Tereblecze (miejscowość na Ukrainie)

Skróty źródeł i literatury

AHR - A lexical atlas of the Hutsul dialects of the Ukrainian language, red. J. Rieger, Warszawa 1996.

Crân - D. Crânjală, Rumunské vlivyv Karpatech se zvláštním zřetelem k moravskému Valašsku, Praha 1938.

ESUM - Етимологічний словник українськоїмови, red. О.С. Мельничук, t. 1-3, Київ 1982-1989.

Hrin - Б. Грінченко, Словарь української мови, Київ 1907-1909. 
Helena Krasowska Problematyka pożyczek ukraińskich w polskiej gwarze górali bukowińskich

JSiat1 - J.Siatkowski, Językowe wpływy niemieckie w Karpatach, t. 2 (w 5 tomie OKAD), w: Kontakty językowe polszczyzny na pograniczu wschodnim, red. E. Wolnicz-Pawłowska, W. Szulowska, Warszawa 2000, s. 231-238.

Kurz - Z. Kurzowa, Polszczyzna Lwowa i Kresów południowo-wschodnich do 1939 roku, Warszawa 1985.

Mih - G. Mihăila, Împrumuturi vechi sud-slave în limba română, București 1960.

OKAD - Общекарпатский диалектологический атлас. Вступительный выпуск, Скопье 1987; t. 1, Кишинев 1989; t. 2, Москва 1994; t. 3, Варшава 1991; t. 4, Киев 1993; t. 5, Братислава 1997.

Rob - I. Robciuc, Raporturile lingvistice româno-ukrainene, București 1996.

Rud - J.B. Rudnyc'kyj, An etymological dictionary of the Ukrainian language, t. 2, Ottawa-Montreal 1978-1982.

SBF - K. Feleszko, Bukowina moja miłość. Język polski na Bukowinie karpackiej. Słownik, red. E. Rzetelska-Feleszko, Warszawa 2003.

SBuk - Матеріали до словника буковинських говірок, t. 1-6, Чернівці 1971-1979.

SGPK - J. Karłowicz, Słownik gwar polskich, t. 1-4, Kraków 1900-1911.

SHJ - J. Janów, Słownik huculski, red. J. Rieger, Kraków 2001.

SJPD - Słownik języka polskiego, red. W. Doroszewski, t. 1-11, Warszawa 1958-1969.

Skok - P.Skok, Etymologijski rječnik hrvatskoga ili srpskoga jezika, t. 1-4, Zagreb 1971-1974.

SEJPS - F.Sławski, Słownik etymologiczny języka polskiego, t. 1 nn., Kraków 1952 i nn.

SRP - Słownik rumuńsko-polski, red. J. Reychman, Warszawa 1970.

Vasmer - М. Фасмер, Этимологический словарь русского языка, t. 1-4, Москва 1964-1973.

WSRP - Wielki słownik rosyjsko-polski / Большой русско-польский словарь, red. A. Mirowicz, I. Dulewiczowa, I. Grek-Pabisowa, I. Maryniakowa, t. 1-2, Warszawa 1996.

Inne stosowane skróty

$\begin{array}{ll}\text { buk. } & \text { - bukowiński } \\ \text { bułg. } & \text { - bułgarski } \\ \text { dem. } & \text { - deminutivum } \\ \text { f. } & \text { - femininum, rodzaj żeński } \\ \text { flek. } & \text { - fleksyjny } \\ \text { franc. } & \text { - francuski } \\ \text { huc. } & \text { - huculski } \\ \text { jw. } & \text { - jak wyżej } \\ \text { jęz. } & \text { - język } \\ \text { lit. } & \text { - literacki } \\ \text { m. } & \text { - masculinum, rodzaj męski } \\ \text { mołd. } & \text { - mołdawski } \\ \text { niem. } & \text { - niemiecki } \\ \text { ogpol. } & \text { - ogólnopolski } \\ \text { ogsłow. } & \text { - ogólnosłowiański } \\ \text { pol. } & \text { - polski, polszczyzna }\end{array}$

$\begin{array}{ll}\text { por. } & \text { - porównaj } \\ \text { pot. } & \text { - potoczny } \\ \text { prasłow. } & \text { - prasłowiański } \\ \text { przen. } & \text { - przenośny } \\ \text { reg. } & \text { - regionalny } \\ \text { rum. } & \text { - rumuński } \\ \text { słc. } & \text { - słowacki } \\ \text { słow. } & \text { - słowiański } \\ \text { tur. } & \text { - turecki } \\ \text { tur.-tatar. - turecko-tatarski } \\ \text { ukr. } \quad \text { - ukraiński } \\ \text { węg. } \quad \text { - węgierski } \\ \text { wschsłow.- wschodniosłowiański } \\ \text { wys. } \quad \text { - występuje } \\ \text { znacz. } \quad \text { - znaczenie } \\ \text { zob. } \quad \text { - zobacz }\end{array}$


Helena Krasowska Problematyka pożyczek ukraińskich w polskiej gwarze górali bukowińskich

\section{Bibliografia}

Crânjală, D. (1938). Rumunské vlivy v Karpatech se zvláštním zřetelem k moravskému Valašsku [Crân]. Praha: Orbis.

Doroszewski, W. (Red.). (1958-1969). Słownik języka polskiego [SJPD] (T. 1-11). Warszawa: PWN.

Feleszko, K. (1992). Język polski na Bukowinie do roku 1945: Zarys problematyki. W: J. Rieger (Red.), Studia nad polszczyzna kresowa (T. 6). Warszawa „Semper”.

Feleszko, K. (2003). Bukowina moja miłość: Język polski na Bukowinie karpackiej: Słownik [SBF] (E. Rzetelska-Feleszko, Red.). Warszawa: Slawistyczny Ośrodek Wydawniczy (IS PAN).

Janów, J. (2001). Słownik huculski [SHJ] (J. Rieger, Red.). Kraków: Wydawnictwo Naukowe DWN. Jurecki, M. (2000). Bukowina kraina łagodności: Przewodnik turystyczny. Kraków: „Bezdroża”. Karłowicz, J. (1900-1911). Słownik gwar polskich [SGPK] (T. 1-6). Kraków: Akademia Umiejętności. Kurzowa, Z. (1985). Polszczyzna Lwowa i Kresów południowo-wschodnich do 1939 roku [Kurz]. Warszawa: PWN.

Mihăila, G. (1960). Imprumuturi vechi sud-slave în limba română [Mih]. București: Editura Academiei Republicii Populare Romîne.

Mirowicz, A., Dulewiczowa, I., Grek-Pabisowa, I., \& Maryniakowa, I. (Red.). (1996). Wielki słownik rosyjsko-polski [Большой русско-польский словарь] [WSRP] (Т. 1-2). Warszawa: Państwowe Wydawnictwo Wiedza Powszechna.

Reychman, J. (Red.). (1970). Słownik rumuńsko-polski [SRP]. Warszawa: Państwowe Wydawnictwo Wiedza Powszechna.

Rieger, J. (Red.). (1996). A lexical atlas of the Hutsul dialects of the Ukrainian language [AHR]. Warszawa: „Semper”.

Robciuc, I. (1996). Raporturile lingvistice româno-ukrainene [Rob]. București: Mustang.

Rudnyc'kyj, J. B. (1978-1982). An etymological dictionary of the Ukrainian language [Rud] (T. 2). Ottawa-Montreal: Ukrainian Free Academy of Sciences.

Siatkowski, J. (2000). Językowe wpływy niemieckie w Karpatach, II (w V tomie OKAD) [JSiat1]. W: E. Wolnicz-Pawłowska \& W. Szulowska (Red.), Kontakty językowe polszczyzny na pograniczu wschodnim (ss. 231-238). Warszawa: „Semper”.

Skok, P. (1971-1974). Etymologijski rječnik hrvatskoga ili srpskoga jezika [Skok] (T. 1-4). Zagreb: Jugoslavenska Akademija Znanosti i Umjetnosti.

Sławski, F. (1952-). Słownik etymologiczny języka polskiego [SEJPS] (T. 1). Kraków: Towarzystwo Miłośników Języka Polskiego.

Грінченко, Б. (1907-1909). Словарь української мови [Hrin]. Київ: Видавництво Української Академії Наук РСР.

Матеріали до словника буковинських говірок [SBuk]. (1971-1979) (Т. 1-6). Чернівці: Кафедра української мови.

Мельничук, О. С. (Red.). (1982-1989). Етимологічний словник української мови [ESUM] (Т. 1-3). Київ: Видавництво Української Академії Наук РСР.

Общекарпатский диалектологический атлас: Вступительный выпуск [OKAD]. (1987). Скопйе: Македонская академия наук и искусств.

Общекарпатский диалектологчческий атлас [OKAD]. (1989) (Т. 1). Кишинев: Штиинца. 
Helena Krasowska Problematyka pożyczek ukraińskich w polskiej gwarze górali bukowińskich

Общекарпатский диалектологический атлас [OKAD]. (1994) (Т. 2). Москва: Институт славяноведения и балканистики.

Общекарпатский диалектологический атлас [OKAD]. (1991) (Т. 3). Варшава: Komitet Językoznawstwa Polskiej Akademii Nauk.

Общекарпатский диалектологический атлас [OKAD]. (1993) (Т. 4). Львів: Інститут українознавства.

Общекарпатский диалектологический атлас [OKAD]. (1997) (Т. 5). Братислава: Veda.

Столбунова, В. И. (1979). Молдавские лексические заимствования в русских народных говорах на Буковине. Черновцы: ЧГУ.

Фасмер, М. (1964-1973). Этимологический словарь русского языка [Vasmer] (T. 1-4). Москва: „Прогресс”.

\section{Bibliography (Transliteration)}

Crânjală, D. (1938). Rumunské vlivy v Karpatech se zvláštním zřetelem k moravskému Valašsku [Crân]. Praha: Orbis.

Doroszewski, W. (Ed.). (1958-1969). Słownik języka polskiego [SJPD] (Vols. 1-11). Warszawa: PWN. Fasmer, M. (1964-1973). Etimologicheskiŭ slovar' russkogo iazyka [Vasmer] (Vols. 1-4). Moskva: "Progress."

Feleszko, K. (1992). Język polski na Bukowinie do roku 1945: Zarys problematyki. In J. Rieger (Ed.), Studia nad polszczyzna kresowa (Vol. 6). Warszawa: "Semper."

Feleszko, K. (2003). Bukowina moja miłość: Język polski na Bukowinie karpackiej: Słownik [SBF] (E. Rzetelska-Feleszko, Ed.). Warszawa: Slawistyczny Ośrodek Wydawniczy (IS PAN).

Hrinchenko, B. (1907-1909). Slovar' ukraïns'koï movy [Hrin]. Kyïv: Vydavnytstvo Ukraïns'koï Akademiï Nauk RSR.

Janów, J. (2001). Słownik huculski [SHJ] (J. Rieger, Ed.). Kraków: Wydawnictwo Naukowe DWN. Jurecki, M. (2000). Bukowina kraina łagodności: Przewodnik turystyczny. Kraków: "Bezdroża.” Karłowicz, J. (1900-1911). Słownik gwar polskich [SGPK] (Vols. 1-6). Kraków: Akademia Umiejętności.

Kurzowa, Z. (1985). Polszczyzna Lwowa i Kresów południowo-wschodnich do 1939 roku [Kurz]. Warszawa: PWN.

Materialy do slovnyka bukovyns'kykh hovirok [SBuk]. (1971-1979) (Vols. 1-6). Chernivtsi: Kafedra ukraïns'koï movy.

Mel'nychuk, O.S. (Ed.). (1982-1989). Etymolohichnyı̆ slovnyk ukraïns'kö̈ movy [ESUM] (Vols. 1-3). Kyïv: Vydavnytstvo Ukraïns'koï Akademiï Nauk RSR.

Mihăila, G. (1960). Împrumuturi vechi sud-slave în limba română [Mih]. București: Editura Academiei Republicii Populare Romîne.

Mirowicz, A., Dulewiczowa, I., Grek-Pabisowa, I., \& Maryniakowa, I. (Eds.). (1996). Wielki słownik rosyjsko-polski [Bol'shoŭ russko-pol'skiŭ slovar'] [WSRP] (Vols. 1-2). Warszawa: Państwowe Wydawnictwo Wiedza Powszechna. 
Helena Krasowska Problematyka pożyczek ukraińskich w polskiej gwarze górali bukowińskich

Obshchekarpatskiŭ dialektologicheskiŭ atlas: Vstupitel'ny̌̆ vypusk [OKAD]. (1987). Skopǐe: Makedonskaia akademiia nauk i iskusstv.

Obshchekarpatskiu dialektologicheskiu atlas [OKAD]. (1989) (Vol. 1). Kishinev: Shtiintsa.

Obshchekarpatskiŭ dialektologicheskĭ atlas [OKAD]. (1994) (Vol. 2). Moskva: Institut slavianovedeniia i balkanistiki.

Obshchekarpatskii dialektologicheskiŭ atlas [OKAD]. (1991) (Vol. 3). Varshava: Komitet Językoznawstwa Polskiej Akademii Nauk.

Obshchekarpatskiŭ dialektologicheskiŭ atlas [OKAD]. (1993) (Vol. 4). L'viv: Instytut ukraïnoznavstva.

Obshchekarpatskiu dialektologicheskiu atlas [OKAD]. (1997) (Vol. 5). Bratislava: Veda.

Reychman, J. (Ed.). (1970). Słownik rumuńsko-polski [SRP]. Warszawa: Państwowe Wydawnictwo Wiedza Powszechna.

Rieger, J. (Ed.). (1996). A lexical atlas of the Hutsul dialects of the Ukrainian language [AHR]. Warszawa: "Semper."

Robciuc, I. (1996). Raporturile lingvistice româno-ukrainene [Rob]. Bucureşti: Mustang.

Rudnyc'kyj, J. B. (1978-1982). An etymological dictionary of the Ukrainian language [Rud] (Vol. 2). Ottawa-Montreal: Ukrainian Free Academy of Sciences.

Siatkowski, J. (2000). Językowe wpływy niemieckie w Karpatach, T. 2 (w V tomie OKAD) [JSiat1]. In E. Wolnicz-Pawłowska \& W. Szulowska (Eds.), Kontakty językowe polszczyzny na pograniczu wschodnim (pp. 231-238). Warszawa: "Semper."

Skok, P. (1971-1974). Etymologijski rječnik hrvatskoga ili srpskoga jezika [Skok] (Vols. 1-4). Zagreb: Jugoslavenska Akademija Znanosti i Umjetnosti.

Sławski, F. (1952-). Słownik etymologiczny języka polskiego [SEJPS] (Vol. 1). Kraków: Towarzystwo Miłośników Języka Polskiego.

Stolbunova, V. I. (1979). Moldavskie leksicheskie zaimstvovaniia v russkikh narodnykh govorakh na Bukovine. Chernovtsy: ChGU.

\section{The problem of Ukrainian borrowings in the Polish dialect of Bukovinian highlanders}

\section{Summary}

The article is based on dialectal material, collected from Bukovinian highlanders according to the guidelines published in the All-Carpathian Dialect Atlas, in which a considerable role is played by Ukrainian vocabulary. The latter has been divided into two groups: 1) natively Ukrainian words; and 2) words that are borrowings in Ukrainian, and that have become part of the Bukovinian highlanders' lexicon 
presumably via Ukrainian. Noteworthy in the first group (Ukrainian borrowings) are the words commonly used in all six studied villages. The Ukrainian lexemes used in four or five of the villages either: a) while having a Slavic origin, are also known in Romanian; or b) are words of Proto-Slavic origin. Finally, borrowings appearing in one, two or three villages can probably be explained by the influence of the state language on the dispersed highlander population.

In the second group of borrowings, i.e., farther borrowings in Ukrainian, the most frequent of subgroups are Hungarian borrowings into Romanian and Ukrainian. Another subgroup are Latin borrowings, which must have been passed to Ukrainian through Romanian, as well as direct or indirect borrowings from Turkish. The material also features borrowings from Romanian, German via Polish, and French.

Ukrainian borrowings in the Polish dialect of Bukovinian highlanders are a difficult interpretational and classificatory problem. The question of whether the highlanders borrowed these words from Ukrainian or Romanian cannot be answered unambiguously, especially since between 1918 and 1944 Bukovina was a part of Romania and Romanian was the language of education, official communication etc. Similarly, we do not know if the words originating from Romanian have been borrowed directly from this language or via Ukrainian. The same can be applied to Hungarian and German. The presented material can thus only be treated as one part of the vocabulary of the Bukovinian highlanders' dialect.

\section{Problematyka pożyczek ukraińskich w polskiej gwarze górali bukowińskich}

\section{Streszczenie}

W przeanalizowanym materiale, zebranym wśród polskich górali bukowińskich na podstawie kwestionariusza Ogólnokarpackiego atlasu dialektologicznego, znaczną rolę odgrywa słownictwo ukraińskie. Zostało ono podzielone na dwie grupy: 1) rodzime wyrazy ukraińskie i 2) pożyczki przejęte z innych języków przez język ukraiński, które znalazły się w polskiej gwarze górali bukowińskich zapewne za jego pośrednictwem. W pierwszej grupie 
(pożyczki ukraińskie) zwracają uwagę wyrazy występujące powszechnie we wszystkich sześciu zbadanych wsiach, związane z życiem codziennym. Leksemy występujące w czterech lub pięciu wsiach można natomiast podzielić na: a) znane też w języku rumuńskim, które przeszły ze słowiańskiego; b) wyrazy prasłowiańskie. Wreszcie pożyczki występujące w jednej, dwóch lub trzech wsiach można prawdopodobnie wyjaśnić wpływem języka państwowego na rozproszoną ludność góralską.

W drugiej grupie pożyczek, tzn. pożyczkach dalszych w języku ukraińskim, na pierwszy plan wysuwają się pożyczki węgierskie w języku rumuńskim i ukraińskim. Kolejną podgrupę tworzą pożyczki z łaciny, które musiały przejść przez język rumuński do ukraińskiego; znajdują się tu także pożyczki z języka tureckiego w ukraińskim lub poprzez turecki. W zebranym materiale znajdziemy także zapożyczenia z języka rumuńskiego, z niemieckiego za pośrednictwem polskiego oraz z języka francuskiego.

Zapożyczenia ukraińskie w polskiej gwarze górali bukowińskich stanowią poważny problem interpretacyjny i klasyfikacyjny. Na pytanie, czy górale przyjęli te pożyczki z ukraińskiego czy z rumuńskiego, nie można dać jednoznacznej odpowiedzi; tym bardziej że Bukowina w okresie od 1918 do 1944 roku należała do Rumunii i język rumuński był językiem szkól, urzędów itd. Nie wiadomo także, czy wyrazy pochodzenia rumuńskiego przeszły przez język ukraiński, czy też zapożyczone zostały bezpośrednio. To samo dotyczy języka węgierskiego i niemieckiego. Przedstawiony materiał może być więc traktowany tylko jako jedna z części ogólnego zasobu słownikowego gwary górali bukowińskich.

Keywords: Polish dialect in Bukovina; Ukrainian borrowings; Carpathian Bukovina; Bukovinian highlanders; language contact in Bukovina

Słowa kluczowe: polska gwara na Bukowinie; zapożyczenia ukraińskie; Bukowina Karpacka; górale bukowińscy; kontakty językowe na Bukowinie

\footnotetext{
Helena Krasowska, Institute of Slavic Studies, Polish Academy of Sciences, Warsaw Correspondence: bukowinianka@wp.pl

This academic publication was financed within the "National Programme for the Development of Humanities" of the Minister of Science and Higher Education in 2015-2018, Project no. 1bH 15035483.

Competing interests: The author has declared she has no competing interests.
} 